\title{
Niche Party Success and Mainstream Party Policy Shifts - How Green and Radical Right Parties Differ in Their Impact
}

\author{
TARIK ABOU-CHADI*
}

\begin{abstract}
This article investigates the impact of niche party success on the policy agendas of mainstream parties. Following from the expected electoral effects of issue politicization, the success of radical right and green parties will cause different reactions from mainstream parties. While mainstream parties emphasize anti-immigrant positions in response to radical right success, green party success will have the opposite effect for environmental issues. Since green parties constitute issue owners, their success will make established parties de-emphasize the environment. Analyzing time-series cross-section data for sixteen Western European countries from 1980 to 2011, this article empirically establishes that green and radical right parties differ in their effect on mainstream party behavior and that their impact depends on the ideological position and past electoral performance of the mainstream parties.
\end{abstract}

The emergence and electoral success of radical right and green parties in several Western democracies has motivated a considerable amount of political science research. It has been argued that these so-called niche parties have a distinct and novel impact on patterns of political competition, since in contrast to other parties, they rarely adapt to shifts in public opinion ${ }^{1}$ and emphasize issues that depart from traditional socio-economic cleavages. ${ }^{2}$ Green parties and radical right parties mostly compete on a single issue (the environment and immigration, respectively). While a larger part of scholarly attention has been dedicated to the ex ante supplyand demand-side conditions for radical right and green party success, ${ }^{3}$ a growing body of research deals with the question of how the emergence of niche parties restructures multiparty competition and the behavior of established parties. Empirical research indeed indicates that established parties react to other parties' policy positioning ${ }^{4}$ as much as to the electoral success of niche parties. ${ }^{5}$ In this sense, niche parties are increasingly regarded as 'issue entrepreneurs' because they contribute to the evolution and politicization of new political issues. ${ }^{6}$ Scholars have argued that successful radical right (and left) parties determine the politicization of European integration in particular, and shape its importance for national political competition. ${ }^{7}$

\footnotetext{
* Humboldt-University, Berlin (email: tarik.abou-chadi@sowi.hu-berlin.de). Earlier versions of this article were presented at the Annual Meeting of the Midwest Political Science Association (2013, Chicago) and at the General Conference of the European Political Science Association (2013, Barcelona). The author wishes to thank Pablo Barberá, Christoffer Green-Pedersen, Ellen Immergut, Martin Kroh, Nicolas Merz, Matthias Orlowski, Wouter van der Brug, Markus Wagner and Bernhard Wessels as well as three anonymous reviewers and the editor for their valuable comments, and the German National Science Foundation for financial support. Data replication sets and online appendices are available at http://dx.doi.org/doi: 10.1017/S0007123414000155.

1 Adams et al. 2006.

2 Wagner 2012a.

3 See, for example, Arzheimer 2009; Kitschelt and McGann 1995; Meguid 2005; Spoon 2011.

4 Adams 2012; Adams and Somer-Topcu 2009.

5 Bale et al. 2010; van Spanje 2010.

6 de Vries and Hobolt 2012; Spoon, Hobolt, and de Vries 2014.

7 Hooghe and Marks 2009.
} 
This perspective, however, does not consider the important role that mainstream parties play in determining whether issues can be established on the political agenda. ${ }^{8}$ There is still no all-encompassing approach to explaining established parties' strategies when confronted with niche party success; nor has this topic been the subject of a broad empirical analysis.

This article aims to fill this gap by providing a framework that predicts established parties' responses to niche party success by building on insights from theories of spatial and issue competition. The main argument is twofold. First, not all niche parties affect established parties in the same way. On the contrary, following from the different expected effects of politicization on partisan realignment, ${ }^{9}$ one should observe that radical right party success leads to an increase in established parties' anti-immigrant positions, whereas green party success will decrease the emphasis on environmental issues. While niche party success always creates some pressure for mainstream parties to pick up their promoted issue, politicization of an issue also entails the risk of strengthening the niche party as a result of the increased salience of this issue. This risk will be considerably higher for green than for radical right parties, because the environment can be seen as an issue with a high valence component and green parties as issue owners. Yet politicization of the immigration issue constitutes an opportunity to mobilize left-authoritarian voters - a strategy that should be especially appealing to moderate right-wing parties. Secondly, the incentives to respond to niche party success are not homogenous across mainstream parties. The ideological positions of mainstream parties determine their coalitional prospects with successful niche parties, and their past electoral performance affects their willingness to adopt new policy profiles. These two factors will thus influence how susceptible established parties are to niche party success.

This study uses data from the Comparative Manifestos Project to investigate the impact of niche party success in a broad time-series cross-section analysis for sixteen Western European countries from 1980 to 2011. The analysis shows that green and radical right parties have different effects, which depend on established parties' characteristics. The results also suggest a causal relationship and reduce the possibility of reverse causality and omitted variable bias, neither of which has often been discussed in other quantitative assessments of similar questions. The findings underline the important role that niche parties play in shaping multiparty competition, however, demonstrating that this role is more nuanced than currently assumed. The developed framework combines perspectives of spatial and issue competition in order to predict parties' strategic behavior in reaction to the politicization of different issue types. Thus it is not limited to radical right and green parties, but can be applied to other parties and issues as well. Moreover, it presents a first step in conceptualizing the role of the interplay of mainstream and niche parties for the politicization and evolution of new issues. It therefore contributes to a bigger literature on party competition, representation and mass-party linkages.

Before explaining the empirical design and elaborating the argument in more detail, the next section will give a brief overview of theories of spatial and issue competition and their relevance for the relationship between niche party success and mainstream party behavior.

\section{THE ROLE OF NICHE PARTIES IN THEORIES OF SPATIAL AND ISSUE COMPETITION}

The evolution of party positions as a result of political competition has been explained following two different traditions of political science research: spatial and issue competition. Based on Anthony Downs' seminal work, political competition can be understood as parties

8 See also Green-Pedersen 2012.

9 This study follows Carmines and Wagner (2006) in conceptualizing partisan realignment as an incremental change linked to issue evolution rather than a radical change that is dependent on crucial elections. 
competing by offering different positions along a policy dimension. ${ }^{10}$ A party's vote share in this spatial conception of political competition is thus determined by the distribution of the electorate on this issue dimension, as people will vote for the party that is ideologically closest to them. ${ }^{11}$ While in a two-party plurality context this should lead to a convergence to the median voter, several scholars have shown how changing conditions such as different party systems, non-policy factors and valence advantages can lead to a mix of centripetal and centrifugal tendencies. ${ }^{12}$ Theories focusing on the supply side of political competition view the degree of convergence to the center and the 'open space' that in turn emerges on the fringes as a main source of the varying success of niche, and especially radical right, parties. ${ }^{13}$ Following this spatial logic of party competition, if radical right parties emerge and gain electoral support, conservative and moderate right-wing parties in particular should be under pressure to move their position to the right in order to prevent them from further success and permanently stealing votes from them. The same holds for left-of-center and green parties. ${ }^{14}$ Empirical studies investigating this 'contagious' effect of niche parties indeed find an association between niche party strength and the repositioning of established parties. ${ }^{15}$

Parties do not compete solely by offering different policy positions but also by emphasizing different issues - preferably issues they 'own'; that is, issues for which a majority of the electorate has traditionally regarded them as competent and effective problem solvers. ${ }^{16}$ This idea of issue competition can be understood as different parties trying to draw attention to different topics such as conservative parties trying to emphasize issues related to law and order or defense, while left-wing parties prefer issues such as social justice, welfare and education. However, it can be shown empirically that parties emphasize not only issues they own, but also overlap considerably in their issue profiles. ${ }^{17}$ One reason for this overlap is that parties cannot freely determine which issues they prefer to emphasize; they have an incentive to react to issues on the party system agenda. ${ }^{18}$ In this sense, by putting a new issue on the agenda and increasing its salience, niche parties can act as issue entrepreneurs and pressure established parties to adapt their behavior accordingly. ${ }^{19}$

Hence, following these theories of spatial and issue competition, the success of green and radical right parties should cause mainstream parties to emphasize the environment and immigration more strongly and shift their position toward the niche party. Indeed, in a recent publication, Spoon, Hobolt and de Vries argue that parties should emphasize environmental issues more in response to the electoral threat posed by successful green parties. ${ }^{20}$ This perspective, however, does not take into account the strategic risk that is involved in reacting to the issues promoted by niche parties. If established parties pick up these issues this will lead to the politicization of an issue; that is, its consolidation on the political agenda. ${ }^{21}$ Politicization will determine which issues are at the top of campaign agendas, and thus affect how important positional distances are for individual vote decisions. This, in turn, may cause partisan

${ }^{10}$ Downs 1957.

${ }^{11}$ Downs 1957; Enelow and Hinich 1982.

12 Adams, Merrill, and Grofman 2005; Cox 1990; Wagner 2012b.

${ }^{13}$ Kitschelt and McGann 1995.

${ }^{14}$ Rohrschneider 1993.

15 Alonso and da Fonseca 2011; Dalton 2009; van Spanje 2010.

${ }^{16}$ Budge and Farlie 1983; Petrocik 1996.

${ }^{17}$ Green-Pedersen 2007.

18 Green-Pedersen and Mortensen 2010.

19 de Vries and Hobolt 2012; Meguid 2008.

${ }^{20}$ Spoon, Hobolt, and de Vries 2014.

${ }^{21}$ Green-Pedersen 2010, 2012. 
realignment, which established parties will take into account when deciding how to react to niche party success. On the one hand, politicization of a new issue might further strengthen the niche party and thereby cause voter movements away from established parties. On the other hand, it can also constitute an opportunity, as it may cause voter shifts from one established party to another, so that some established parties will have an interest in the politicization of an issue.

Politicization, conceptualized in this way, combines perspectives of spatial and issue competition since it results not only from a direct saliency increase but can also be the consequence of positional shifts. Taking or changing a position on an issue promoted by a niche party necessarily means an increase in salience, because parties need to promote this position, which will in turn establish it on the party system agenda. Bonnie Meguid similarly argues that accommodative and adversarial strategies (that is, shifting the position toward or away from the niche party) will make a party more visible in respect of the promoted issue. ${ }^{22}$ While the direct saliency increase through this position taking might be relatively marginal, it is nonetheless difficult to predict the extent of saliency increase, since the mass media in particular can work as an additional agenda setter in response to political developments. ${ }^{23}$ Hence, taking a position on a new issue is always linked to the risk of increasing its salience. Moving toward the position of a niche party will thus be a very costly strategy if the expected voter shifts following politicization move away from the established party. Yet if established parties expect to benefit from the politicization of an issue, they have a big incentive to pick up the issue and move their position.

Building on this argument about the strategic considerations of politicization, the next section will elaborate how the reactions of established parties to niche party success depend on the type of niche party as well as mainstream party characteristics.

\section{THE IMPACT OF NICHE PARTY SUCCESS ON MAINSTREAM PARTY BEHAVIOR}

While most research on niche parties has treated radical right and green parties as substantially the same, or has focused on one of the two types, this section provides a framework that can account for varying strategies of established parties, depending on the risks and opportunities of partisan realignment associated with the politicization of the niche party issue. These risks and opportunities will be different for radical right and green parties, because they compete on different types of issues and vary in their degree of issue ownership. Moreover, these strategic incentives will not be homogenous across mainstream parties, but will vary with their ideological position and electoral performance.

Following Stokes' seminal critique of Downs' spatial theory of voting, it is possible to distinguish between positional and valence issues. ${ }^{24}$ Positional issues are characterized by a set of alternatives on which voters have different preferences, while valence issues are those that are generally seen as positive or negative, and parties compete over competence in them. ${ }^{25}$ These types of issues lead to different dynamics of political competition. Whereas parties' position taking will mainly determine competition over positional issues, issue ownership and salience constitute the key components of competition over valence issues. With green parties campaigning above all on the issue of the environment, and radical right parties focusing on immigration, they represent these two different issue types. This distinction is of course ideal-typical, and one might doubt that issues are either completely valence or completely positional. However, the environment surely constitutes an issue with a high valence

22 Meguid 2008, 94.

23 Walgrave and van Aelst 2006.

24 Stokes 1963.

25 Stokes 1963. 

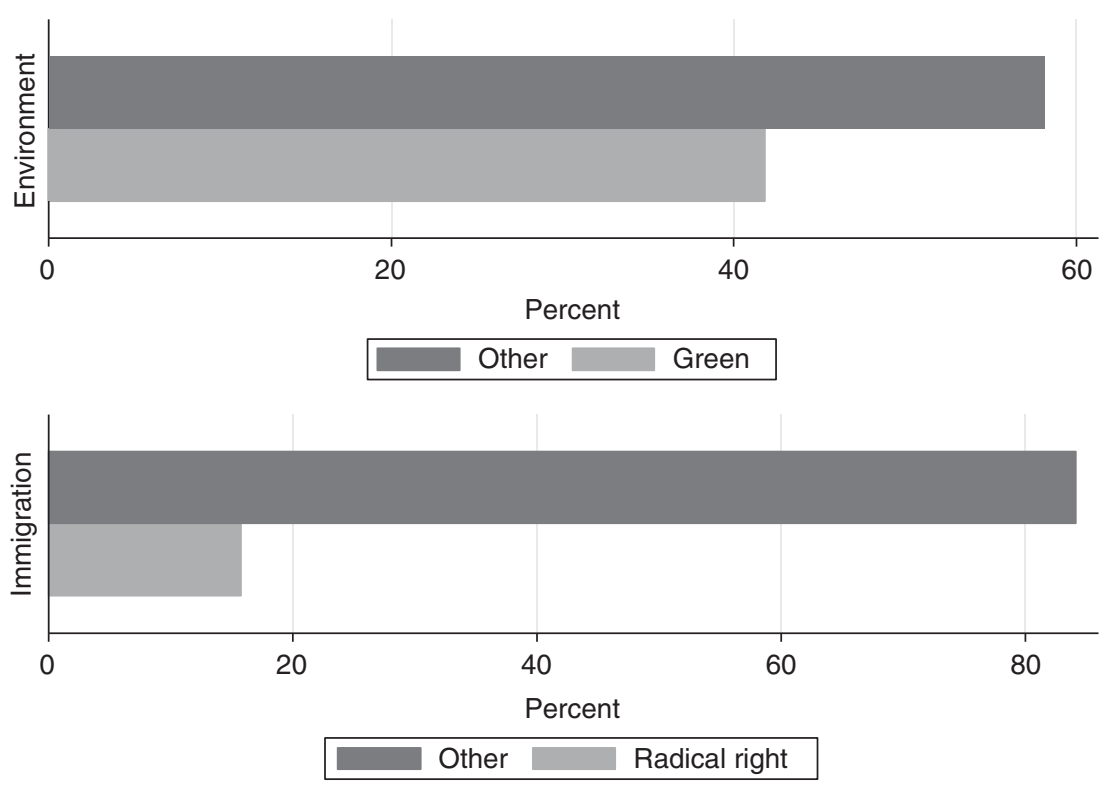

Fig. 1. Issue ownership of green and radical right parties: party competence by most and second-most important problems

component. While there might be different opinions regarding its importance, few voters would not perceive a pollution-free environment as an actual goal. Yet there is far less agreement about immigration in the electorate; positions vary strongly on the questions of how much immigration should be allowed (and from which countries). The first distinction between the two types of parties is thus that right parties compete on a polarized and more positional issue, while green parties compete on an issue with a high valence component. This distinction affects the strategic choices available to established parties. In response to radical right party success, established parties are far more likely to make positional changes on the immigration issue, whereas reactions to green party success will be more limited to the saliency dimension of environmental issues. Moreover, these different issue types are also linked to different degrees of issue ownership, which, in turn, determines the risk of losing supporters to a niche party if an issue is politicized.

As discussed earlier, the concept of issue ownership can be understood as different parties being perceived as being better able to handle specific problems and, thus, benefitting from their salience. More precisely, one should distinguish between a competence and an associative dimension of issue ownership. ${ }^{26}$ Competence represents a party's perceived problem-solving capacity, whereas the associative dimension includes the feeling of intuitively linking a party to an issue. Using data from the third wave of the Comparative Study of Electoral Systems (CSES) in Austria, Finland, France, Germany, the Netherlands and Sweden, Figure 1 shows that green parties' issue ownership (on the competence dimension) of the environment issue is much higher than radical right parties' issue ownership of immigration. ${ }^{27}$

While 42 per cent of those who perceive the environment as the most or second-most important problem name a green party as the most competent to deal with this issue, only 16 per cent do so

26 Walgrave, Lefevere, and Tresch 2012.

27 The Comparative Study of Electoral Systems 2012. 
for immigration and radical right parties. ${ }^{28}$ This difference is statistically highly significant. While there is no broad comparative assessment yet, Walgrave, Lefevere and Tresch find that in Belgium the associative issue ownership of green parties is much higher than that of radical right parties. $^{29}$

Following from the different types of issues on which they compete, as well as their varying degrees of issue ownership, green parties can be expected to benefit much more from the politicization of their issue than radical right parties. For established parties, this means that the risk that politicization of the environment issue will cause partisan realignment in favor of green parties, is very high. As Riker has also shown, if a party is able to dominate political discourse on an issue, other parties have a strategic incentive to drop this issue. ${ }^{30}$ Hence, as soon as green parties gain electoral support, other parties will have an incentive to not compete on environmental issues. This line of argumentation diverges from Spoon, Hobolt and de Vries, who analyze the impact of green party success from an issue-entrepreneurial perspective and show that other parties emphasize environmental issues more, when green parties are successful. ${ }^{31}$ The methods and results sections will elaborate in more detail how the design applied in this study differs from theirs, and how the contrasting findings can be explained.

Since immigration is a strongly positional issue (on which radical right parties are not perceived as dominantly competent), politicization will not necessarily lead to an increase in radical right party strength. Hence, whereas the issue ownership of green parties provides an incentive for established parties to de-emphasize environmental issues in response to green parties' electoral success, this is not the case for radical right parties and the immigration issue. Radical right parties should thus function as issue entrepreneurs, since the costs of not repositioning and not responding to an issue on the agenda outweigh the possible risks of politicizing the immigration issue.

For some established parties, the politicization of the immigration issue should even be beneficial, since it creates an opportunity for partisan realignment toward their party. A substantial share of the Western European electorate can be identified as left-authoritarian. ${ }^{32}$ This part of the electorate, however, lacks representation on the supply side of politics; that is, on the party level. ${ }^{33}$ Having to choose between representation on one of these two dimensions, left-authoritarian voters tend to privilege economic over second-dimension issues such as immigration and European integration, and thus vote for parties located on the left of the economic left-right dimension. ${ }^{34}$ Yet since issue salience affects the degree of issue voting, the politicization of immigration can shift this balance toward the socio-cultural dimension. Emphasizing the immigration issue (and thereby establishing it on the political agenda) can thus be a valuable strategy for conservative and other right-of-center parties to attract left-authoritarian voters. The same mechanism, however, does not hold for mainstream left parties and the environment. Environmental issues can largely be integrated into the

${ }^{28}$ The exact wording of the question is: 'What do you think is the (second) most important political problem facing [COUNTRY] today?' About 6 per cent of the respondents name the environment as the first or secondmost important problem; about 14 per cent do so for immigration. The coding of the answers given to the most important problem question is very diverse among the CSES studies. The sample here is thus limited to countries that are part of the quantitative analysis and with which some homogeneity among these categories could be established.

${ }^{29}$ Walgrave, Lefevere, and Tresch 2012, 5.

${ }^{30}$ Riker 1996.

${ }^{31}$ Spoon, Hobolt, and de Vries 2014.

32 Kitschelt 1994; Kriesi et al. 2006.

33 van der Brug and van Spanje 2009.

${ }^{34}$ Lefkofridi, Wagner, and Willmann 2014. 
socio-economic dimension and, thus, create far less political potential. ${ }^{35}$ Moreover, as outlined before, green parties dominate the discourse on the environment and will be the beneficiaries of partisan realignment in case of politicization.

Hence, taking into account the discussed risks and opportunities resulting from issue politicization, established parties should react differently to radical right and green party success. While the success of niche parties exerts some pressure on mainstream parties to shift their position and put the according issues on the agenda, politicization of an issue always includes the risk of strengthening the according niche parties, thereby causing partisan realignment away from established parties and toward new parties. This risk will be considerably higher for green than for radical right parties, because the environment can be seen as an issue with a high valence component and green parties as owners of this issue. Yet politicization of the immigration issue constitutes an opportunity to appeal to new voter groups, especially those that can be identified as left-authoritarian.

Four hypotheses about the impact of niche party success on the policy agendas of established parties follow from this theoretical framework:

HYPOTHESIS 1a: Increasing radical right party support causes mainstream parties to shift toward anti-immigrant positions.

HYPOTHESIS 1b: Increasing radical right party support causes mainstream parties to emphasize the immigration issue.

HYPOTHESIS 2a: Increasing green party support will not affect mainstream parties' positions on environmental issues.

HYPOTHESIS 2b: Increasing green party support will cause mainstream parties to de-emphasize environmental issues.

While the main distinction made here is about the type of niche party, according to the presented framework, established parties should also vary in their susceptibility to niche party success depending on their own ideological position and past electoral performance. First, politicization of niche party issues affects mainstream parties in a different way because they have different coalition prospects with emerging niche parties. How much the success of a niche party affects the possibilities of getting into office depends on the mainstream party's ideological position. Moderate right-wing parties will have a higher incentive to politicize the immigration issue in response to radical right party success, since these parties constitute a potential partner to form a coalition. ${ }^{36}$ Moreover, as outlined before, using the immigration issue to potentially cause the realignment of left-authoritarian voters who have traditionally identified with left-wing parties will be an especially appealing strategy for mainstream conservative parties. Parties of the left are not only very unlikely to form a coalition with a radical right party, but politicizing the immigration issue might also disqualify parties of the left from coalitions with other left-of-center parties. ${ }^{37}$ The incentive to de-emphasize environmental issues as a response to green party success, on the other hand, should be stronger for right-of-center parties. Green parties are more likely to form a coalition with left-wing parties, and politicizing the environment issue should generally favor parties that are located left of the center.

35 In a detailed analysis of voter and party positions, Kriesi et al. (2008) show that environmental protection can be integrated into the socio-economic left-right dimension. Immigration, however, constitutes a main component of a second, socio-cultural, dimension.

36 Bale 2003.

37 Green-Pedersen and Krogstrup 2008. 
Secondly, since past election results constitute an important source of information about voters' preference distributions, ${ }^{38}$ they will influence parties' predisposition to adopt new issues and change their position. Winners and losers of elections thus have different incentives to respond to niche party success. As has been demonstrated in the literature on issue evolution and party campaigning, parties that have lost votes in a previous election should be more likely to shift their position ${ }^{39}$ or contribute to the politicization of a new issue. ${ }^{40}$ Politicizing immigration in response to radical right party success will be especially appealing to parties that have not performed well in past elections and because of that feel a need to change their profile and campaigning strategies. In contrast, since green parties are issue owners and dominate the discourse on the environment, established parties have an incentive to drop the issue no matter how well they performed in past elections. Three more hypotheses follow from these considerations:

HYPOTHESIS 3a: The more to the right a mainstream party can be located, the more it will shift toward anti-immigrant positions and increase the salience of the immigration issue in response to radical right party success.

HYPOTHESIS 3b: The more to the right a mainstream party can be located, the more it will deemphasize environmental issues in response to green party success.

HYPOTHESIS 4: The more votes a mainstream party has lost at a previous election, the more it will shift toward anti-immigrant positions and increase the salience of the immigration issue in response to radical right party success.

This section provided an encompassing framework to predict the different effects of niche party success on established parties' policy agendas. The next section will test the derived hypotheses in a time-series cross-section analysis of Western European countries.

THE IMPACT OF NICHE PARTIES ON MAINSTREAM PARTY BEHAVIOR - EMPIRICAL

ANALYSIS

These hypotheses will be analyzed using data mainly from the Comparative Manifesto Project. ${ }^{41}$ The dataset is based on the coding of quasi-sentences following fifty-six issue categories that are then used to estimate how much emphasis is put on a given issue in a manifesto. The items thus measure the position and salience of an issue in a manifesto. The dataset contains party manifestos in forty-two countries, many of them dating back to 1945 , and allows the evaluation of the effect of niche party support on mainstream party manifestos cross-nationally and over time. The analyses presented here are based on a subset that includes all significant mainstream parties in sixteen Western European countries from 1980 to $2011^{42}$ The remaining sample includes 521 party manifestos. ${ }^{43}$

38 Budge 1994.

39 Somer-Topcu 2009.

40 Riker 1986, 1996.

41 Budge et al. 2001; Klingemann et al. 2006; Volkens et al. 2012.

42 Parties are coded as mainstream parties if they belong to one of the following party family categories provided by the Manifesto dataset: social democratic, liberal, conservative or Christian democratic. The countries included are: Austria, Belgium, Denmark, Finland, France, Germany, Great Britain, Ireland, Italy, Luxembourg, Netherlands, Norway, Portugal, Spain, Sweden and Switzerland.

43 The number of observations in the statistical analysis is then further reduced due to missing values on the independent variables such as immigration rates. 


\section{Operationalization}

To test the hypotheses, it is necessary to estimate the effect of niche party support on mainstream parties' issue positions as well as issue emphasis. The measure for position is constructed in a similar way to Kim and Fording: in order to obtain a measure of position that is independent of salience, one can use the paired nature of the manifesto data and subtract the summed share of a positive category from the summed share of a negative category. ${ }^{44}$ This difference is then divided by the sum of positive and negative categories. Salience is simply measured by the sum of positive and negative shares.

Since the manifesto data does not include direct items of party positions on immigration, it is measured using item per607 'Multiculturalism: Positive' and item per608 'Multiculturalism: Negative'. Statements against multicultural societies and appeals for cultural homogeneity represent the idea of cultural protectionism, which can be regarded as the main ideological offer presented by radical right parties. ${ }^{45}$ A measure of the position on multiculturalism is then calculated according to the description given above:

$$
\text { Multiculturalism (Pos.) }=\frac{\text { per608-per607 }}{\text { per608+per607 }} \text {. }
$$

The higher a party scores on this measure, the more it represents restrictive policies toward citizenship acquisition and immigration in an election. A measure of the saliency of multiculturalism is calculated as follows:

$$
\text { Multiculturalism }(\text { Sal. })=\text { per608 }+ \text { per607. }
$$

In line with the idea that the environment constitutes a valence issue, there is no pair of environment categories but only one item (per501) representing pro-environment statements. However, in order not to simply assume the non-existence of a positional dimension, item per410, 'Productivity', is used as an opposite of 'Environmental Protection: Positive'. ${ }^{46}$ An emphasis on industrial productivity and economic growth can be regarded as opposed to a focus on a pollution-free environment and more sustainable growth. Position and salience are calculated accordingly:

$$
\begin{aligned}
& \text { Environment }(\text { pos. })=\frac{\text { per } 501-\text { per } 410}{\text { per } 501+\text { per } 410} \\
& \text { Environment }(\text { Sal. })=\text { per } 501+\text { per } 410 .
\end{aligned}
$$

The main independent variables of interest are Radical Right and Green Party Support, measured as their vote share at the previous parliamentary election. ${ }^{47}$ Radical right parties were coded according to Norris and Mudde, and all electoral results are taken from the Parliament and Government Composition Database (ParlGov). ${ }^{48}$ If there was more than one radical right or green party with a vote share high enough to be reported by the ParlGov database, the sum of their vote shares for this election is used to measure the combined amount of pressure that is put

${ }^{44}$ Kim and Fording 2003.

${ }_{45}$ Norris 2005, 166ff.

${ }^{46}$ Additional analyses using different operationalizations of the dependent variable can be found in the online appendix.

${ }^{47}$ One exception is the result of the French Front National in 2002 election. Due to their success in the presidential campaign, they decided not to run in the parliamentary election. For this election, the result of the first round of the presidential election is used.

48 Döring and Manow 2011; Mudde 2007; Norris 2005. 
on mainstream parties. A list of all radical right and green parties included can be found in Appendix Table A1. ${ }^{49}$

All models control for Party Size and whether a party was in Government during the election period before the election manifesto. The information on party size (in vote share) and government status is again based on data from the ParlGov database. The models investigating the impact of radical right support also include a control for the Number of Immigrants. Higher rates of immigration might cause radical right party success as well as influence mainstream party agendas, since they are likely to affect general attitudes concerning immigration. The number of immigrants is measured as the log of the average of incoming migrants in the previous election period. Models on green party support instead include the log of GDP Per Capita (as a proxy for the degree of post-materialism in a society) and a time dummy for the period following the Chernobyl disaster, which increased the salience of environmental issues and created high levels of support for environmental movements and green parties. Summary statistics for all variables can be found in Table A2.

\section{Model Specification}

Several pooled time-series cross-section models are estimated with ordinary least squares to assess the impact of radical right and green party support on mainstream party policy agendas. In order to account for serial correlation and panel-specific heteroskedasticity the models include a lagged dependent variable, and panel-corrected standard errors are calculated. ${ }^{50}$ The lagged dependent variable also has a substantial meaning since party manifestos are not always written from scratch, but are heavily based on previous manifestos. All models also include party-dummy fixed effects to account for unit-specific heterogeneity. The inclusion of the fixed effects reduces the analyzed variation to within-party variation over time, and thus controls for time-constant party- and country-specific particularities. The following two basic models are estimated for issue position and salience, respectively:

$$
\begin{aligned}
\text { Multiculturalism }_{i, t}= & \beta_{0}\left(\text { Multiculturalism }_{i, t-1}\right)+\beta_{1}\left(\text { radicalrightsupport }_{i, t-1}\right) \\
& +\beta_{2}\left(\text { partysize }_{i, t}\right)+\beta_{3}\left(\text { government }_{i, t}\right)+\beta_{4}\left(\text { immigration }_{i, t}\right)+v_{i}+\varepsilon_{i, t}
\end{aligned}
$$

$$
\begin{aligned}
& \text { Environment }_{i, t}=\beta_{0}\left(\text { Environment }_{i, t-1}\right)+\beta_{1}\left(\text { greensupport }_{i, t-1}\right)+\beta_{2}\left(\text { partysize }_{i, t}\right) \\
& +\beta_{3}\left(\text { government }_{i, t}\right)+\beta_{4}\left(G D P_{i, t}\right)+\beta_{5}\left(\text { Chernobyl }_{t}\right)+v_{i}+\varepsilon_{i, t}
\end{aligned}
$$

where $i$ is an indication of party and $t$ of election date.

This design differs in three main respects from Spoon, Hobolt and de Vries, who used Manifesto data to investigate the effect of green party strength on other parties' issue emphasis on environmental protection. ${ }^{51}$ First, in contrast to Spoon, Hobolt and de Vries (who only use per501 as their dependent variable), this study distinguishes between the position and salience of the dependent variable. As will be discussed later, robustness checks using different operationalizations of the dependent variable (including only using per501) confirm the findings of the basic regression models. Secondly, this analysis does not include a measure of green issue

\footnotetext{
49 Since the Portuguese Green Party ran together with the Communist Party from 1987 (see Spoon et al. 2014), one could argue that it should not be counted as a green party. The results presented include the Portuguese Greens, but are robust against excluding Portugal from the analysis.

50 Beck and Katz 1995, 1996.

51 Spoon, Hobolt, and de Vries 2014.
} 
salience among the electorate as a control variable. Such a variable is highly endogenous to the process under investigation here, because party positions and their issue emphases of course determine which problems are regarded as most pressing among citizens. ${ }^{52}$ The most important difference in this design lies in the inclusion of party fixed effects, which is essential for making causal claims about the effect of niche party success on mainstream party behavior. ${ }^{53}$ Limiting the analysis to the variation over time has the essential advantage of controlling for time-constant party and country characteristics that are likely to bias the findings. In particular, this concerns the possibility that the population in some countries might simply be more proenvironment than in others, which would explain both the success of green parties and the issue emphasis/position of mainstream parties. A positive correlation between green party support and mainstream parties' emphasis on environmental protection based on cross-sectional analyses thus involves the high risk of being spurious.

\section{RESULTS}

\section{Main Effects}

Table 1 presents the results for the basic regression models. As can be seen, radical right and green parties do, indeed, differ in their impact on established parties' agendas. ${ }^{54}$ Radical right party support has a significant positive effect. With a growing vote share of a radical right party at the previous election, mainstream parties shift their profile toward a more ethno-cultural and restrictive position on immigration. In response to an increase in radical right party support, mainstream parties equally increase the salience of the multiculturalism issue. An increasing number of immigrants not only causes parties to talk more about immigration, but also to shift their position toward a more restrictive profile. Parties in government, on the other hand, take a more positive position on multiculturalism. The findings in Models 1 and 2 thus support Hypotheses 1a and 1b; radical right parties function as issue entrepreneurs and exert the contagious effect that has been found in other studies. Green party support, on the other hand, has no significant effect on mainstream party positions on environmental issues. The sign of the b-coefficient is even negative, indicating that, facing green party success, established parties move away from a pro-environment position. With an increase in green party vote share, mainstream parties, however, significantly decrease the salience of environmental issues in their manifestos. Hence, as predicted by the presented framework and in line with Hypotheses 2a and $2 \mathrm{~b}$, facing a successful issue owner, established parties do not change their position in the direction of the niche party and de-emphasize the promoted issue.

These results have important implications for the study of niche parties, multiparty competition and mass-elite linkages. The finding that actual levels of immigration affect parties' positions and issue salience supports the dynamic representation model of political parties ${ }^{55}$ and demonstrates how globalization and de-nationalization are reshaping the political space in

\footnotetext{
52 This becomes even more problematic considering that the according item in the Eurobarometer data is only measured at three time points during the period 1979 to 2001. Simply imputing the values for the other time periods seems questionable.

53 The F-tests for models only including the party fixed effects indeed show that they are statistically significant. Figure A1 in the online appendix additionally presents the variation in their effects for the four basic models.

54 The difference in the number of observations between the position and valence models is due to the calculation procedure. If a manifesto does not include any statements belonging to one of the categories, this will lead to a missing value for the position variable, while it will be zero for salience.

55 Stimson, Mackuen, and Erikson 1995.
} 
TABLE $1 \quad$ Results of Basic Regression Models

\begin{tabular}{lcclcc}
\hline \hline & $\begin{array}{c}(1) \\
\text { Multiculturalism } \\
\text { position }\end{array}$ & $\begin{array}{c}\text { Multiculturalism } \\
\text { salience }\end{array}$ & & $\begin{array}{c}(3) \\
\text { Environment } \\
\text { position }\end{array}$ & $\begin{array}{c}\text { Environment } \\
\text { salience }\end{array}$ \\
\hline Lagged DV & 0.018 & $0.411^{*}$ & Lagged DV & 0.043 & 0.187 \\
& $(0.117)$ & $(0.160)$ & & $(0.104)$ & $(0.108)$ \\
Radical Right & $\mathbf{0 . 0 3 2 * *}$ & $\mathbf{0 . 0 8 5 * *}$ & Green Party & $\mathbf{- 0 . 0 3 0}$ & $\mathbf{- 0 . 4 5 6 * *}$ \\
Support $(\boldsymbol{t}-\mathbf{1})$ & $\mathbf{( 0 . 0 0 8 )}$ & $\mathbf{( 0 . 0 3 2 )}$ & Support $(\boldsymbol{t}-\mathbf{1})$ & $\mathbf{( 0 . 0 1 7 )}$ & $\mathbf{( 0 . 1 6 5})$ \\
Immigration & $0.164^{* *}$ & $0.282^{*}$ & GDP Per & 0.193 & 0.986 \\
(log) & $(0.028)$ & $(0.113)$ & Capita $(\log )$ & $(0.106)$ & $(0.716)$ \\
Party Size & -0.010 & 0.023 & Party Size & 0.004 & $0.069^{*}$ \\
& $(0.010)$ & $(0.019)$ & & $(0.006)$ & $(0.034)$ \\
Government & $-0.233^{* *}$ & -0.272 & Government & 0.048 & $0.732^{*}$ \\
Party & $(0.074)$ & $(0.250)$ & Party & $(0.048)$ & $(0.309)$ \\
& & & Chernobyl & -0.046 & $1.863^{* *}$ \\
Party Fixed & & & Party Fixed & $(0.084)$ & $(0.697)$ \\
Effects & & & Effects & & \\
Observations & 202 & 365 & Observations & 406 & 429 \\
R-squared & 0.732 & 0.590 & R-squared & 0.625 & 0.833 \\
\hline \hline
\end{tabular}

Note: panel-corrected standard errors in parentheses. $* * \mathrm{p}<0.01, * \mathrm{p}<0.05$.

Western Europe. ${ }^{56}$ While confirming the contagious effect of radical right parties, they contradict the idea that green party success is the driving force behind the evolution of environmental issues. On the contrary, in line with Green-Pedersen, these findings emphasize the role of mainstream parties and their anticipation of electoral consequences when analyzing issue evolution and the politicization of issues. ${ }^{57}$

\section{Robustness and Causality}

The functional form of the models in Table 1 including levels (instead of differences) of the dependent and independent variables as well as a lagged dependent variable assumes an instantaneous response function with a geometrically decaying effect of $\beta_{1}$ of the size of $\beta_{0}{ }^{58}$ An autoregressive distributed lag (ADL) model (that is, including an additional lag of the independent variable) would permit a more flexible adaption rate and would thus allow the investigation of a more nuanced dynamic relationship over time. However, since the size of $t$ in this study is rather small (we are dealing with elections and not country-years), the information to estimate these additional parameters is limited, which makes this procedure problematic for the data at hand. In order to get an impression of these dynamics, however, Appendix Table A3 presents the results of an ADLLDV2 (ADL with two lagged dependent variables) model, which allows us to assess the nature of the dynamic relationship due to the nested structure of these models. ${ }^{59}$ Three of the four additional lagged independent variables (vote share of radical right and green parties at $t-2$ ) are far from statistical significance, implying instantaneous adaption

56 Kriesi et al. 2008.

57 Green-Pedersen 2012.

58 Beck and Katz 2011.

59 Beck and Katz 2011, 340. 
rates. None of the additional lagged dependent variables reaches statistical significance, which supports the use of the functional form specified in Equations 1 and 2. Only Model 4, which estimates the effect of green party support on the salience of environmental issues, shows an additional significant negative lag for green party support. This finding implies that established parties might de-emphasize environmental issues in response to green parties' electoral success with a certain time lag. Due to the rather limited number of elections per country, however, these findings should be interpreted cautiously and at best seen as indicative. The following analyses are again based on the levels specification presented in Equations 1 and 2.

As an additional robustness check, Tables A4 and A5 present the effect of radical right and green party support on different measures of the respective dependent variable. The measurement of the dependent variable in Table A4 follows Alonso and da Fonseca, who suggest a different operationalization of immigration using the Manifesto data. ${ }^{60}$ Here, too, we find a statistically significant positive effect of the vote share of radical right parties on anti-immigrant positioning and the salience of immigration issues. Table A5 presents the regression results for two alternative measures of environmental issues. First, only per501 (Environmental Protection: Positive) is used as a dependent variable. While this makes it impossible to fully distinguish between changes in position and salience, this specification allows a more straightforward comparison with the effects found by Spoon et al., ${ }^{61}$ who use exactly this dependent variable to measure the salience of environmental protection. Secondly, Models 2 and 3 present estimates for another dependent variable adding an additional item per416 (Anti-Growth Economy: Positive) to our earlier operationalization. A focus on anti-growth policies and sustainable development can be regarded as an additional positive mentioning of the environment, representing a contrast to the category productivity. As Model 1 in Table A5 shows, green party support has a negative effect on pro-environment statements, confirming the earlier findings. In response to green party success, mainstream parties indeed de-emphasize environmental protection. Models 2 and 3 are also in line with the hypotheses showing that green party success does not significantly affect positions on the environment, while established parties significantly de-emphasize the salience of environmental issues with an increase in green party vote share. Using different operationalizations of the dependent variables thus confirms the findings in Table 1.

Two main problems arise in interpreting these effects as a causal impact of niche party success on mainstream party behavior: reverse causality and omitted variable bias. As Meguid has convincingly argued, the success of niche parties is highly dependent on mainstream party strategies. ${ }^{62}$ Hence it is possible that established parties' issue strategies on immigration and the environment determine niche party vote share and not the other way around, as has been argued here. A simple Granger reverse causality model ${ }^{63}$ constitutes a possibility to assess reverse causality by running regression models using the dependent variable at $t-1$ to predict the independent variable at time $t .^{64}$ As Models 1 and 3 in Table A6 show, a party's position on immigration or the environment does not significantly affect the vote share of radical right or green parties at the subsequent election, which weakens the case of reverse causality for these models. Model 4 shows a significant effect of environmental salience on green party support.

60 Alonso and da Fonseca 2011.

61 Spoon et al. 2013.

62 Meguid 2005, 2008.

63 Sargent 1976.

${ }^{64}$ It should be mentioned that since these regressions use single party positions/emphases as their independent variable, they cannot serve as a direct test for Meguid's theory, which is based on party system characteristics (the issue strategies of several parties). 
However, since this effect is positive, reverse causality constitutes a bias against our earlier findings, which describe a negative impact of green party support on salience of the environment. Finally, Model 2 shows a significant positive effect of a party's immigration emphasis on radical right party success. This does indeed indicate that reverse causality constitutes a potential problem when interpreting the effect of radical right support on mainstream parties' emphasis of the immigration issue. It is thus not possible to fully identify a causal effect for this relationship, which should rather be interpreted as correlational.

A second problem for interpreting the effects as a causal impact of niche party success arises from possible omitted variable bias. While one might find an association between increasing the vote share of niche parties and movements toward their emphasized issues by established parties, this could be caused by shifts in public attitudes. The literature on party competition has convincingly demonstrated that mainstream parties indeed react to shifts in public opinion. ${ }^{65}$ Hence, if public opinion determines both mainstream parties' issue position/emphasis and niche party success, then one would find an association without any causal link between the two. Looking at the results presented here, however, this constitutes a problem only for the impact of radical right parties and not for green parties. It is possible that a shift toward an anti-immigrant public attitude causes radical right success as well as a higher share of manifestos dedicated to cultural protectionism. However, it is rather implausible that a not-observed condition should increase green party vote share and at the same time decrease environmental issues in party manifestos. Moreover, the inclusion of the lagged dependent variable partly controls for this omitted variable bias, insofar as it captures the effect of public opinion on party positions at $t-1$. The actual bias is thus reduced to the scenario in which public opinion influences the vote share of a radical right party at $t-1$ and party positions at $t$, but has not influenced party positions at $t-1$. In sum, the findings indicate that niche party success has a causal impact on mainstream party agendas, and that this effect differs according to the type of niche party.

\section{Mainstream Party Positions and Past Electoral Performance}

In order to investigate the effects proposed in the other hypotheses, two interactions have been added to the basic models successively. As stated in Hypotheses 3a and 3b, parties located more to the right should be more likely to shift their position and emphasize immigration, but have a bigger incentive to de-emphasize environmental issues in response to the according niche party success. Hence, there should be an interaction between a party's left-right placement and niche party support. The index for the general Left-Right Position used here is provided by the Manifesto data (rile). It theoretically ranges from -100 to 100 (higher values indicate that a party is further to the right). It should be emphasized that the index for left-right positioning of a party does not include the items used as dependent variables here. The rile measure derived from the Manifesto data has been subject to considerable criticism. ${ }^{66}$ However, it remains the only measure of parties' left-right position that is time variant and available for the time under investigation here. As an additional robustness check, Table A9 and Figure A2 present results using a composite measure of the average standardized values of the rile measure and Benoit and Laver's expert measure of a party's left-right position. ${ }^{67}$ Hypothesis 4 states that electoral losers are more susceptible to radical right party success. In order to test this hypothesis, an additional interaction with Vote Difference has been added, indicating vote gains/losses as the

65 Adams et al. 2004; Adams et al. 2006.

66 Gemenis 2013.

67 Benoit and Laver 2006. 



Fig. 2. Marginal effect of niche party success conditional on left-right position Note: dashed lines give $95 \%$ confidence intervals.

difference in vote share between $t-1$ and $t-2$. While no relationship was hypothesized for green party success, the results are presented in order to underline this claim.

Since the main effects of interest are the interactions of two continuous variables, the best way to interpret them is a marginal effects plot, ${ }^{68}$ which can be found in Figures 2 and 3 . The according regression tables can be found in the online appendix (Tables A7 and A8).

Figure 2 shows how the effect of niche party support varies with the left-right position of an established party. The positive effect of radical right support on anti-immigrant positions and issue emphasis increases as a party moves to the right along the left-right scale. This indicates that right-of-center parties are more inclined to politicize the immigration issue. This is in line with the expectation that radical right success due to coalitional perspectives presents less of a threat to these parties, and that they can use this strategy to appeal to left-authoritarian voters. Yet there is still a significant positive effect for center and moderate left-wing parties, which is especially pronounced for positional changes. This indicates that even left-of-center parties on average choose an accommodative strategy and emphasize anti-immigrant positions when facing an increase in radical right support. Yet no matter where a mainstream party can be located on the left-right scale, there is no significant marginal effect of green party vote share on positional shifts on the environment issue. However, confirming Hypothesis $3 \mathrm{~b}$, the further a party is located to the right, the more it de-emphasizes environmental issues in response to green party success. Nevertheless, one can still observe a significant negative marginal effect for more left-wing parties. Hence, while it is more pronounced for parties to the right, all mainstream party families de-emphasize environmental issues when facing the increasing strength of an

68 Brambor, Clark, and Golder 2005. 

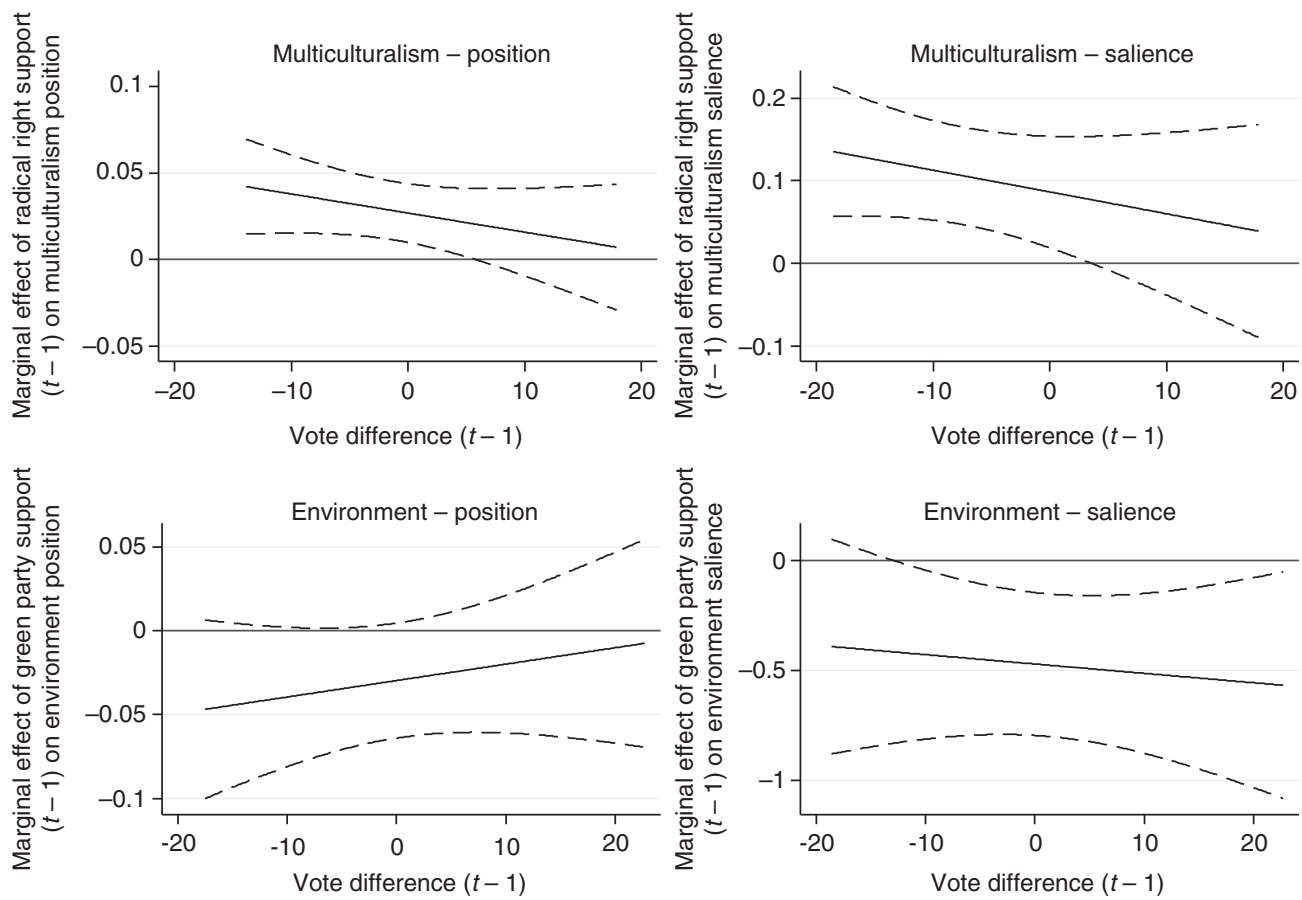

Fig. 3. Marginal effect of niche party success conditional on vote difference at $\mathrm{t}-1$ Note: dashed lines give $95 \%$ confidence intervals.

issue owner. These findings also contradict a purely spatial interpretation of the impact of niche party success on mainstream party strategies. Following a spatial logic of political competition, one should observe right-wing parties reacting more strongly to radical right party success and left-wing parties reacting more strongly to green party success. This, however, is not the case for the countries and time period studied here. First, although right-of-center parties react more strongly to radical right success, they also de-emphasize the environment more in response to increasing green party support. Secondly, a wide range of parties reacts to niche party success particularly by emphasizing and de-emphasizing issues. This highlights the important role that issue salience plays in assessing the impact of niche parties on multiparty competition.

Finally, Figure 3 confirms that parties that have lost votes in a previous election react more strongly to radical right party success than those that performed better. The more votes a party has lost in the previous election, the more it shifts its position and emphasizes multiculturalism in response to an increase in radical right vote share. These parties indeed follow a logic of dispersion and engage in strategies that will lead to the politicization of an issue they perceive as likely to cause partisan realignment. In contrast, with green parties dominating the discourse on the environment, their success provides an incentive to de-emphasize the issue independently of past electoral performance.

In sum, the results presented here support the hypotheses derived from a new approach that takes into account considerations of spatial and issue competition in order to predict mainstream parties' responses to niche party success. These parties act strategically, and choose their positions and issue emphases according to the electoral consequences that can be expected from 
the politicization of an issue. However, their reactions are not homogenous among all parties, but depend on their ideological position and past election results.

\section{CONCLUSION}

This article has quantitatively assessed the impact of niche party success on mainstream party policy strategies, and shown how this effect varies according to the type of niche party. The success of radical right parties provides an incentive for established parties (especially of the moderate right) to shift their position toward a cultural protectionist profile and to emphasize the immigration issue in order to appeal to left-authoritarian voters. In response to green party success, however, parties de-emphasize the environment issue because a successful issue owner of this topic has entered the field. These mechanisms and strategic considerations vary with ideological position and the past electoral performance of the established parties. Right-wing parties and electoral losers change their immigration policy agendas more strongly in response to radical right success than left-of-center parties. Moreover, mainstream parties located more to the right tend to de-emphasize environmental issues more when facing the electoral gains of a green party. These findings and insights on the strategic behavior of mainstream parties in response to niche party success have important implications for the analysis of multiparty competition and issue evolution.

First, they underline the important role that both spatial and issue competition play in determining political parties' behavior and reactions to each other. Dynamic representation should thus not only be understood in terms of parties' positions, but equally needs to take into account their issue emphases. While theories of spatial and issue competition have mostly been presented as two competing theories about party competition, nothing in the general nature of these theories rules out including insights from both perspectives. The dynamics of saliency and position are crucial to understanding the impact of radical right and green parties on mainstream parties, and they are very likely to have equally intertwined effects for other types of parties and in other areas of multiparty competition.

Secondly, while niche parties play an important role in explaining issue evolution, this study shows that niche party success does not necessarily lead to the politicization of their promoted issues. Mainstream parties react strategically and assess the possible effect that politicization of a certain issue will have on their future electoral performance. Further research will be needed to explore whether these findings also hold for other types of niche parties and the issues on which they compete. Moreover, analyses of electoral behavior will help investigate the micro-level mechanisms that have been assumed in this study of party behavior.

\section{REFERENCES}

Adams, James. 2012. Causes and Electoral Consequences of Party Policy Shifts in Multiparty Elections: Theoretical Results and Empirical Evidence. Annual Review of Political Science 15:401-19.

Adams, James, Michael Clark, Lawrence Ezrow, and Garrett Glasgow. 2004. Understanding Change and Stability in Party Ideologies: Do Parties Respond to Public Opinion or to Past Election Results? British Journal of Political Science 34:589-610.

- 2006. Are Niche Parties Fundamentally Different from Mainstream Parties? The Causes and the Electoral Consequences of Western European Parties' Policy Shifts, 1976-1998. American Journal of Political Science 50:513-29.

Adams, James, Samuel Merrill, and Bernard Grofman. 2005. A Unified Theory of Party Competition: A Cross-National Analysis Integrating Spatial and Behavioral Factors. Cambridge and New York: Cambridge University Press. 
Adams, James, and Zeynep Somer-Topcu. 2009. Policy Adjustment by Parties in Response to Rival Parties' Policy Shifts: Spatial Theory and the Dynamics of Party Competition in Twenty-Five Post-War Democracies. British Journal of Political Science 39:825.

Alonso, Sonia, and Saro Claro da Fonseca. 2011. Immigration, Left and Right. Party Politics 18:1-20.

Arzheimer, Kai. 2009. Contextual Factors and the Extreme Right Vote in Western Europe, 1980-2002. American Journal of Political Science 53:259-75.

Bale, Tim. 2003. Cinderella and Her Ugly Sisters: The Mainstream and Extreme Right in Europe's Bipolarising Party Systems. West European Politics 26:67-90.

Bale, Tim, Christoffer Green-Pedersen, André Krouwel, Kurt Richard Luther, and Nick Sitter. 2010. If You Can't Beat Them, Join Them? Explaining Social Democratic Responses to the Challenge from the Populist Radical Right in Western Europe. Political Studies 58:410-26.

Beck, Nathaniel, and Jonathan N. Katz. 1995. What to Do (and Not to Do) with Time-Series-Cross-Section Data in Comparative Politics. American Political Science Review 89:634-47.

1996. Nuissance vs. Substance: Specifying and Estimating Time-Series-Cross-Section Models. Political Analysis 6:1-36.

— 2011. Modeling Dynamics in Time-Series-Cross-Section Political Economy Data. Annual Review of Political Science 14:331-52.

Benoit, Kenneth, and Michael Laver. 2006. Party Policy in Modern Democracies. New York: Routledge. Brambor, Thomas, William R. Clark, and Matt Golder. 2005. Understanding Interaction Models: Improving Empirical Analyses. Political Analysis 14:63-82.

Budge, Ian. 1994. A New Spatial Theory of Party Competition: Uncertainty, Ideology and Policy Equilibria Viewed Comparatively and Temporally. British Journal of Political Science 24:443-67.

Budge, Ian, and Dennis Farlie. 1983. Explaining and Predicting Elections: Issue Effects and Party Strategies in Twenty-Three Democracies. London: George Allen \& Unwin.

Budge, Ian, Hans-Dieter Klingemann, Andrea Volkens, Judith Bara, and Eric Tanenbaum. 2001. Mapping Policy Preferences: Estimates for Parties, Electors, and Governments 1945-1998. Oxford and New York: Oxford University Press.

Carmines, Edward G., and Michael W. Wagner. 2006. Political Issues and Party Alignments: Assessing the Issue Evolution Perspective. Annual Review of Political Science 9:67-81.

The Comparative Study of Electoral Systems. 2012. CSES Module 3 Third Advance Release [dataset]. Available from www.cses.org.

Cox, Gary W. 1990. Centripetal and Centrifugal Incentives in Electoral Systems. American Journal of Political Science 34:903-35.

Dalton, Russell J. 2009. Economics, Environmentalism and Party Alignments: A Note on Partisan Change in Advanced Industrial Democracies. European Journal of Political Research 48:161-75.

de Vries, Catherine E., and Sara B. Hobolt. 2012. When Dimensions Collide: The Electoral Success of Issue Entrepreneurs. European Union Politics 13:246-68.

Döring, Herbert, and Philip Manow. 2011. Parliament and Government Composition Database (ParlGov): An Infrastructure for Empirical Information on Parties, Elections and Governments in Modern Democracies. Version 11/07. Available from parlgov.org, accessed 15 July 2013.

Downs, Anthony. 1957. An Economic Theory of Democracy. New York: Harper \& Row.

Enelow, James M., and Melvin J. Hinich. 1982. Ideology, Issues, and the Spatial Theory of Elections. American Political Science Review 76:493-501.

Gemenis, Kostas. 2013. What to Do (and Not to Do) with the Comparative Manifestos Project Data. Political Studies 61:3-23.

Green-Pedersen, Christoffer. 2007. The Growing Importance of Issue Competition: The Changing Nature of Party Competition in Western Europe. Political Studies 55:607-28.

2010. New Issues, New Cleavages, and New Parties: How to Understand Change in West European Party Competition. Paper prepared for the Annual Conference of the American Political Science Association, 2-5 September, Washington, DC.

2012. A Giant Fast Asleep? Party Incentives and the Politicisation of European Integration. Political Studies 60:115-30. 
Green-Pedersen, Christoffer, and Jesper Krogstrup. 2008. Immigration as a Political Issue in Denmark and Sweden. European Journal of Political Research 47:610-34.

Green-Pedersen, Christoffer, and Peter B. Mortensen. 2010. Who Sets the Agenda and Who Responds to it in the Danish Parliament? A New Model of Issue Competition and Agenda-Setting. European Journal of Political Research 49:257-81.

Hooghe, Liesbet, and Gary Marks. 2009. A Postfunctionalist Theory of European Integration: From Permissive Consensus to Constraining Dissensus. British Journal of Political Science 39:1-23.

Kim, Heemin, and Richard C. Fording. 2003. Voter Ideology in Western Democracies: An Update. European Journal of Political Research 42:95-105.

Kitschelt, Herbert. 1994. The Transformation of European Social Democracy. Cambridge and New York: Cambridge University Press.

Kitschelt, Herbert, and Anthony McGann. 1995. The Radical Right in Western Europe: A Comparative Analysis. Ann Arbor: University of Michigan Press.

Klingemann, Hans-Dieter, Andrea Volkens, Judith Bara, Ian Budge, and Michael D. McDonald. 2006. Mapping Policy Preferences II: Estimates for Parties, Electors and Governments in Central and Eastern Europe, European Union and OECD 1990-2003. Oxford and New York: Oxford University Press.

Kriesi, Hans-Peter, Edgar Grande, Romain Lachat, Martin Dolezal, Simon Bornschier, and Timotheos Frey. 2006. Globalization and the Transformation of the National Political Space: Six European Countries Compared. European Journal of Political Research 45:921-56.

2008. West European Politics in the Age of Globalization. Cambridge, UK and New York: Cambridge University Press.

Lefkofridi, Zoe, Markus Wagner, and Johanna E. Willmann. 2014. Left-Authoritarians and Policy Representation in Western Europe: Electoral Choice Across Ideological Dimensions. West European Politics 37:1-26.

Meguid, Bonnie M. 2005. Competition Between Unequals: The Role of Mainstream Party Strategy in Niche Party Success. American Political Science Review 99:347-59.

2008. Party Competition Between Unequals: Strategies and Electoral Fortunes in Western Europe. Cambridge: Cambridge University Press.

Mudde, Cas. 2007. Populist Radical Right Parties in Europe. Cambridge: Cambridge University Press.

Norris, Pippa. 2005. Radical Right: Voters and Parties in the Electoral Market. Cambridge and New York: Cambridge University Press.

Petrocik, John. 1996. Issue Ownership in Presidential Elections with a 1980 Case Study. American Journal of Political Science 40:825-50.

Riker, William H. 1986. The Art of Political Manipulation. New Haven, CT: Yale University Press.

- 1996. The Strategy of Rhetoric: Campaigning for the American Constitution. New Haven, CT: Yale University Press.

Rohrschneider, Robert. 1993. New Party Versus Old Left Realignments: Environmental Attitudes, Party Policies, and Partisan Affiliations in Four West European Countries. Journal of Politics 55:682-701.

Sargent, Thomas J. 1976. A Classical Macroeconometric Model for the United States. Journal of Political Economy 84:207-38.

Somer-Topcu, Zeynep. 2009. Timely Decisions: The Effects of Past National Elections on Party Policy Change. Journal of Politics 71:238-48.

Spoon, Jae-Jae. 2011. Political Survival of Small Parties in Europe. Ann Arbor: University of Michigan Press.

Spoon, Jae-Jae, Sara B. Hobolt, and Catherine E. de Vries. 2014. Going Green: Explaining Issue Competition on the Environment. European Journal of Political Research 53:363-80.

Stimson, James A., Michael B. Mackuen, and Robert S. Erikson. 1995. Dynamic Representation. American Political Science Review 89:543-65.

Stokes, Donald E. 1963. Spatial Models of Party Competition. American Political Science Review 57:368-77. 
van der Brug, Wouter, and Joost van Spanje. 2009. Immigration, Europe and the 'New' Cultural Dimension. European Journal of Political Research 48:309-34.

van Spanje, Joost. 2010. Contagious Parties: Anti-Immigration Parties and Their Impact on Other Parties' Immigration Stances in Contemporary Western Europe. Party Politics 16:563-86.

Volkens, Andrea, Onawa Lacewell, Pola Lehmann, Sven Regel, Henrike Schultze, and Annika Werner. 2012. The Manifesto Data Collection. Manifesto Project (MRG/CMP/MARPOR). Berlin: Wissenschaftszentrum Berlin für Sozialforschung.

Wagner, Markus. 2012a. Defining and Measuring Niche Parties. Party Politics 18:845-64.

- 2012b. When do Parties Emphasise Extreme Positions? How Strategic Incentives for Policy Differentiation Influence Issue Importance. European Journal of Political Research 51:64-88.

Walgrave, Stefaan, Jonas Lefevere, and Anke Tresch. 2012. The Associative Dimension of Issue Ownership. Public Opinion Quarterly 76:771-82.

Walgrave, Stefaan, and Peter van Aelst. 2006. The Contingency of the Mass Media's Political Agenda Setting Power: Toward a Preliminary Theory. Journal of Communication 56:88-109. 